\title{
Interface behavior between garnet-type lithium-conducting solid electrolyte and lithium metal
}

\author{
R. Sudo, Y. Nakata, K. Ishiguro, M. Matsui, A. Hirano, Y. Takeda, O. Yamamoto ${ }^{*}$, N. \\ Imanishi \\ Graduate School of Engineering, Mie University, Tsu Mie, 514-8507, Japan
}

\begin{abstract}
$\mathrm{Al}_{2} \mathrm{O}_{3}$ was doped $(0.5,1.0$. and $2.0 \mathrm{wt} \%)$ into the garnet-type lithium ion-conducting solid electrolyte with a nominal composition of $\mathrm{Li}_{7} \mathrm{La}_{3} \mathrm{Zr}_{2} \mathrm{O}_{12}$ (LLZ) by solid state reaction at $1,180{ }^{\circ} \mathrm{C}$. The effect of the $\mathrm{Al}_{2} \mathrm{O}_{3}$ content in $\mathrm{LLZ}$ on the interface behavior with lithium metal was investigated. The lowest interface resistance was observed for $0.5 \mathrm{wt} \% \mathrm{Al}_{2} \mathrm{O}_{3}$-doped $\mathrm{LLZ}$, which had the highest relative density of 93.7\%. The $\mathrm{Li} / \mathrm{Al}_{2} \mathrm{O}_{3}$-doped LLZ/Li cell showed a short circuit after a limited polarization period. Short circuiting is considered to be due to lithium dendrite formation. The longest period until short circuit was $1,000 \mathrm{~s}$. polarization at $0.5 \mathrm{~mA} \mathrm{~cm}{ }^{-2}$ and room temperature for the $0.5 \mathrm{wt} \% \mathrm{Al}_{2} \mathrm{O}_{3}$ doped $\mathrm{LLZ}$.
\end{abstract}

\section{Introduction}

The high lithium ion conducting and lithium stable solid electrolyte of $\mathrm{Li}_{7} \mathrm{La}_{3} \mathrm{ZrO}_{12}$ (LLZ) was reported by Weppner's group in 2007 [1]. The ionic conductivity of a sintered pellet (92\% theoretical density) was reported to be $2.44 \times 10^{-4} \mathrm{~S} \mathrm{~cm}^{-1}$ at $25{ }^{\circ} \mathrm{C}$. This lithium conducting solid is quite attractive for application in all-solid-state lithium batteries and also in aqueous lithium-air batteries because it is stable under atmosphere and in contact with lithium metal, as well as in water with a high content of $\mathrm{LiCl}$ [2]. However, for such applications, the interface properties between LLZ and lithium metal should be clarified to establish the optimal conditions for excellent battery performance. The interface behavior between lithium metal and solid lithium conductors has not been well studied except for that with lithium conducting solid polymer electrolytes [3-5]. Lithium dendrite formation on lithium metal electrodes is a serious problem in non-aqueous solutions [6]. Lithium dendrite formation was suppressed by using polymer electrolytes, but is still observed at a high current density [3]. We expect that lithium dendrite formation could be completely suppressed by the use of a hard solid electrolyte. Kotobuki et al. reported abnormal behavior at high current density from chronopotentiograms measured for the Li/LLZ/Li cell with LLZ pellets sintered at 
$1230{ }^{\circ} \mathrm{C}$ for $36 \mathrm{~h} \mathrm{[7].} \mathrm{At} \mathrm{current} \mathrm{densities} \mathrm{up} \mathrm{to} 10 \mu \mathrm{A} \mathrm{cm}^{-2}$, the lithium deposition and stripping potential curves gave a mirrored relationship at least until $600 \mathrm{~s}$. However, an abrupt increase in cell voltage was observed after polarization for $70 \mathrm{~s}$ at $50 \mu \mathrm{A} \mathrm{cm}^{-2}$; however, no comment on this phenomenon was given. Ohta et al. [8] measured the impedance of a $\mathrm{Li} / \mathrm{Li}_{6.75} \mathrm{La}_{3} \mathrm{Zr}_{1.75} \mathrm{Nb}_{0.25} \mathrm{O}_{12}(\mathrm{LLZ}-\mathrm{Nb}) / \mathrm{Li}$ cell to be around $1,000 \Omega \mathrm{cm}^{2}$ at room temperature, where LLZ-Nb was sintered at $1,200{ }^{\circ} \mathrm{C}$ for $36 \mathrm{~h}$. The cell resistance is mainly due to the interface resistance between $\mathrm{Li}$ and LLZ-Nb. The $\mathrm{Li} / \mathrm{LLZ}-\mathrm{Nb} / \mathrm{LiCoO}_{2}$ cell was only operated at a low current density of $3.5 \mu \mathrm{A} \mathrm{cm}{ }^{-2}$; therefore, the interface resistance should be reduced to operate at a high current density. Nakata et al. [9] reported that $\mathrm{Li} / \mathrm{LLZ}$ prepared at $1,180{ }^{\circ} \mathrm{C} / \mathrm{Li}$ cell had a low cell resistance of around $50 \Omega \mathrm{cm}^{2}$ at room temperature. The interface behavior between LLZ and lithium metal may be dependent on the electrical conductivity, impurity phases, and the grain boundary properties of the LLZ. High conducting cubic LLZ that was previously reported contained aluminum as a contaminant from the alumina crucible used during high temperature sintering $[2,10]$. Aluminum is considered to stabilize the high conducting cubic phase at room temperature [10, 11]. Rangasamy et al. [11] observed that at least 0.204 moles of $\mathrm{Al}$ is required to stabilize cubic phase LLZ at room temperature. In this study, the effects of the aluminum concentration in LLZ on the interface resistance between lithium metal and LLZ and lithium dendrite formation have been examined.

\section{Experimental}

LLZ was prepared by conventional solid state reaction using chemical grade. $\mathrm{LiCO}_{3}$, $\mathrm{La}_{2} \mathrm{O}_{3}$ and $\mathrm{ZrO}_{2}$ (Nacalai Tesque). $\mathrm{La}_{2} \mathrm{O}_{3}$ was dried at $1,000{ }^{\circ} \mathrm{C}$ for $1 \mathrm{~h}$. The molar ratio of $\mathrm{Li}: \mathrm{La}: \mathrm{Zr}$ was controlled to be 7.7:3:2. Excess $\mathrm{Li}$ was added to compensate for expected Li loss during high temperature heat treatment. The powders were ball-milled with zirconia balls and isostatically pressed into pellets at $150 \mathrm{MPa}$ and then calcined at $900{ }^{\circ} \mathrm{C}$ for $5 \mathrm{~h}$. The reaction products were ball-milled again and isostatically pressed into pellets and calcined at $950{ }^{\circ} \mathrm{C}$ for $12 \mathrm{~h}$. The calcined pellets were then ball-milled with $\gamma-\mathrm{Al}_{2} \mathrm{O}_{3}$ (Alfa) and pressed into pellets and placed in alumina crucibles, covered with mother powder (prepared at $950{ }^{\circ} \mathrm{C}$ for $12 \mathrm{~h}$ ), and sintered at $1,180{ }^{\circ} \mathrm{C}$ for $36 \mathrm{~h}$ under an air atmosphere.

X-ray diffraction (XRD) patterns were obtained using a Rigaku RINT 2500 diffractometer with a rotating copper cathode. Elemental analysis for $\mathrm{Li}, \mathrm{La}, \mathrm{Al}$, and $\mathrm{Zr}$ was conducted using inductively coupled plasma spectroscopy (ICP; Shimadzu ICP 1000). A powder sample was dissolved into a mixed solution of concentrated nitric acid and hydrochloride acid (1:3 v/v) for ICP analysis. The electrical conductivity of sintered 
samples (1.0 cm diameter and ca. $0.1 \mathrm{~cm}$ thick) with gold-sputtered electrodes was measured using an impedance phase analyzer (Solartron 1260) in the frequency range of $0.1 \mathrm{~Hz}$ to $1 \mathrm{MHz}$ with the voltage set at $10 \mathrm{mV}$. A Li/LLZ/Li cell was prepared by sandwiching lithium metal foil (Honjo Metal, $200 \mu \mathrm{m}$ thick) with a $\mathrm{Cu}$ thin foil lead and LLZ in a plastic envelope. The envelope was then evacuated, heat-sealed and subjected to an isostatic pressure of $150 \mathrm{MPa}$ to ensure good contact between the Li and LLZ. ZView software was employed for data analysis and presentation of the impedance results.

\section{Results and discussion}

All XRD peaks of undoped LLZ were assigned to the garnet-type cubic structure reported by Awaka et al. [12]. with a lattice constant of $1.29679 \mathrm{~nm}$, which is slightly smaller than that of a single crystal of Al-containing LLZ (1.29751 nm) [10] and is comparable with that of polycrystalline LLZ $(1.29682 \mathrm{~nm})$ reported by Murugan et al. [1]. The XRD patterns of the $\mathrm{Al}_{2} \mathrm{O}_{3}$-doped $\mathrm{LLZ}$ samples were also assigned to the cubic phase, and tetragonal LLZ and impurity phases such as $\mathrm{LaAlO}_{3}$ and $\mathrm{La}_{2} \mathrm{Zr}_{2} \mathrm{O}_{7}$ were below the detection limit. Rangasamy et al. [11] reported the effect of the $\mathrm{Al}$ and $\mathrm{Li}$ concentrations on the formation of cubic garnet for the nominal composition of $\mathrm{Li}_{7} \mathrm{La}_{3} \mathrm{Zr}_{2} \mathrm{O}_{12}$ prepared at $1,000{ }^{\circ} \mathrm{C}$ for $4 \mathrm{~h}$ using boron nitride coated $\mathrm{Al}_{2} \mathrm{O}_{3}$ combustion boats. It was determined that at least $\underline{0.65 \mathrm{wt} \%}$ of $\mathrm{Al}$ is required to stabilize the cubic phase. Table 1 shows the $\mathrm{Li}$ and $\mathrm{Al} \mathrm{wt} \%$ normalized according to the $\mathrm{Zr}$ content of 2 in $\mathrm{Li}_{7} \mathrm{La}_{3} \mathrm{Zr}_{2} \mathrm{O}_{12}$, lattice constant, and the relative density of the sintered pellets of $\mathrm{Al}_{2} \mathrm{O}_{3}$-doped LLZ. The $\mathrm{Al}$ content of the undoped LLZ was $0.6 \mathrm{wt} \%$, where the aluminum originates from the alumina crucible used during sintering. The LLZ samples sintered in alumina crucibles at $1,180{ }^{\circ} \mathrm{C}$ were stabilized to the cubic phase at room temperature by the aluminum contaminant. The $\mathrm{Al}$ content was slightly increased by the intentional addition of $\mathrm{Al}_{2} \mathrm{O}_{3}$ into LLZ. The lattice constants of the $\mathrm{Al}_{2} \mathrm{O}_{3}$-doped LLZ samples were not changed systematically with the $\mathrm{Al}_{2} \mathrm{O}_{3}$ content, because the lattice constant was dependent on both the $\mathrm{Al}$ and $\mathrm{Li}$ contents. The relative density of the sintered pellets was estimated from the ratio of the density calculated from the lattice constant and that calculated from the weight and volume. The highest density of $93.7 \%$ was observed for $0.5 \mathrm{wt} \% \mathrm{Al}_{2} \mathrm{O}_{3}$-doped LLZ. The pellet density was decreased by further doping $\mathrm{Al}_{2} \mathrm{O}_{3}$. Kumazaki et al. [13] reported that the relative density of $1.3 \mathrm{wt} \%$ $\mathrm{Al}_{2} \mathrm{O}_{3}$-doped LLZ sintered at $1230{ }^{\circ} \mathrm{C}$ for $36 \mathrm{~h}$ was $87 \%$, and Jin et al. [14] reported the relative densities of 0.7 and $1.2 \mathrm{wt} \% \mathrm{Al}_{2} \mathrm{O}_{3}$-doped $\mathrm{LLZ}$ sintered at $1,200{ }^{\circ} \mathrm{C}$ for $6 \mathrm{~h}$ to be 88 and $86 \%$, respectively. These LLZ samples were sintered using alumina crucibles or alumina plate. The aluminum contents in these sintered samples were not reported. The 
alumina content of these sintered samples may be higher than that of the $0.5 \mathrm{wt} \% \mathrm{Al}_{2} \mathrm{O}_{3}$ doped LLZ due to the higher sintering temperatures, which suggests that the high content of alumina in LLZ reduces the relative density.

Figure 1 shows impedance profiles measured for $\mathrm{Au} / \mathrm{Al}_{2} \mathrm{O}_{3}$-doped $\mathrm{LLZ} / \mathrm{Au}$ at $25{ }^{\circ} \mathrm{C}$ in the frequency range of $0.1 \mathrm{~Hz}$ to $1 \mathrm{MHz}$ as a function of the doped $\mathrm{Al}_{2} \mathrm{O}_{3}$ content. All the impedance profiles show a semicircle in the frequency range of $1 \mathrm{M} \mathrm{Hz}$ to $100 \mathrm{k} \mathrm{Hz}$ followed by a straight line. The semicircle is attributed to the grain boundary resistance and the intercept of the semicircle with the real axis at high frequency represents the bulk resistance of the sample [15]. Table 2 summarizes the conductivity data obtained for $\mathrm{Al}_{2} \mathrm{O}_{3}$-doped LLZ. The bulk conductivity was not significantly changed by the addition of $\mathrm{Al}_{2} \mathrm{O}_{3}$ into LLZ, while the grain boundary conductivity of the undoped LLZ $\left(4.17 \times 10^{-4} \mathrm{~S} \mathrm{~cm}^{-1}\right)$ was enhanced to $1.67 \times 10^{-3} \mathrm{~S} \mathrm{~cm}^{-1}$ by the addition of $0.5 \mathrm{wt} \% \mathrm{Al}_{2} \mathrm{O}_{3}$. Further addition of $\mathrm{Al}_{2} \mathrm{O}_{3}$ resulted in a decrease of the grain boundary conductivity. The total conductivity of LLZ is comparable to that reported by Murugan et al. [1]. The highest total conductivity of $4.12 \times 10^{-4} \mathrm{~S} \mathrm{~cm}^{-1}$ was observed for $0.5 \mathrm{wt} \% \mathrm{Al}_{2} \mathrm{O}_{3}$-doped LLZ. The total conductivity value is comparable to that of hot-pressed $\mathrm{Li}_{6.24} \mathrm{La}_{3} \mathrm{Zr}_{2} \mathrm{Al}_{0.24} \mathrm{O}_{11.89}$ (relative density: 98\%), of which the grain boundary resistance was low [11]. Geiger et al. [10] suggested that Al substitutes for Li in LLZ, but the limit of the amount of substitution has not been clarified. A limited amount of $\mathrm{Al}_{2} \mathrm{O}_{3}$ may contribute to a reduction in the grain boundary resistance.

The stability of $\mathrm{Al}_{2} \mathrm{O}_{3}$-doped $\mathrm{LLZ}$ in contact with lithium is an important requirement for all-solid-state batteries and for application as the protective layer for a water-stable lithium metal electrode. The resistance of the Li/LLZ/Li cell decreased with storage period for the first one week and then became stable for one month at room temperature. Figure 2 shows impedance profiles of the $\mathrm{Li} / \mathrm{Al}_{2} \mathrm{O}_{3}$-doped $\mathrm{LLZ} / \mathrm{Li}$ cell after one week at room temperature. Diminished semicircles were observed in these impedance profiles. The high frequency range semicircles in the frequency range of $1 \mathrm{M}$ $\underline{\mathrm{Hz}}$ to $100 \mathrm{k} \mathrm{Hz}$ were observed for $\mathrm{Au} / 0,0.5$ and $1 \mathrm{wt} \% \mathrm{Al}_{2} \underline{\mathrm{O}}_{3}$-doped LLZ/Au and correspond to the grain boundary resistance of LLZ. The semicircle in the low frequency range may correspond to the interface layer resistance produced between $\underline{\text { lithium metal and } \mathrm{Al}_{2}} \underline{\mathrm{O}}_{3}$-doped LLZ and the charge transfer resistance [16]. The lowest $\mathrm{Li} / \mathrm{LLZ} / \mathrm{Li}$ cell resistance of $95 \Omega \mathrm{cm}^{2}$ was observed for the $\mathrm{Li} / 0.5 \mathrm{wt} \% \mathrm{Al}_{2} \mathrm{O}_{3}$-doped $\mathrm{LLZ/Li} \mathrm{cell,} \mathrm{which} \mathrm{is} \mathrm{lower} \mathrm{than} \mathrm{those} \mathrm{reported} \mathrm{for} \mathrm{Li/polymer} \mathrm{electrolyte/Li} \mathrm{cells} \mathrm{at}$ $60{ }^{\circ} \mathrm{C}[16,17]$.

Kotobuki et al. [7] reported an abnormal cell voltage increase for $\mathrm{Li} / \mathrm{LLZ} / \mathrm{Li}$ at $50 \mu \mathrm{A}$ $\mathrm{cm}^{-2}$ after $70 \mathrm{~s}$ polarization, where the LLZ pellet was sintered at $1,230{ }^{\circ} \mathrm{C}$ for $36 \mathrm{~h}$ and the LLZ conductivity was $1.8 \times 10^{-4} \mathrm{~S} \mathrm{~cm}^{-1}$ at room temperature. Recently, Ishiguro et al. [18] reported that the $\mathrm{Li} / \mathrm{Nb}-$ doped $\mathrm{LLZ} / \mathrm{Li}$ cll showed a short circuit for $230 \mathrm{~s}$ 
polarization at $0.5 \mathrm{~mA} \mathrm{~cm}{ }^{-2}$ and no short circuit for $41 \mathrm{~h}$ polarization at $0.1 \mathrm{~mA} \mathrm{~cm}^{-2}$. We have examined the dc current behavior of $\mathrm{Li} / \mathrm{Al}_{2} \mathrm{O}_{3}$-doped LLZ/Li cells at room temperature. Figure 3 shows the cell voltage change with the polarization period at 0.5 $\mathrm{mA} \mathrm{cm}{ }^{-2}$. The cell with undoped LLZ shows an abrupt drop in cell voltage after $122 \mathrm{~s}$ polarization. An abrupt voltage drop was observed for the $\mathrm{Li} / 0.5 \mathrm{wt} \% \mathrm{Al}_{2} \mathrm{O}_{3}$-doped LLZ/Li cell after 1,000 s polarization. The abrupt cell voltage drop could be explained by lithium dendrite formation, which results in short circuiting of the cell [5]. Figure 4 shows a surface morphology change of $0.5 \mathrm{wt} \% \mathrm{Al}_{2} \underline{\mathrm{O}}_{3}$-doped LLZ by the lithium deposition using the visible $\mathrm{Li} / \mathrm{LLZ} / \mathrm{LiClO}_{4} \underline{\text { in EC}}_{\mathrm{EEC} / \mathrm{Li} \text { cell. Several black circles are }}$ observed after $280 \mathrm{~s}$ polarization at $0.5 \mathrm{~mA} \mathrm{~cm}^{-2}$ and the diameter of these black circles are increased by the further polarization. The black circles may be due to the lithium dendrite growth through the grain boundaries and voids in LLZ. The practical application of LLZ for all-solid-state batteries and as a protective layer in lithium air-batteries will require higher current densities, such as several milliamps per square centimeter or more, to be passed through the cell for long periods without lithium dendrite formation and with low lithium deposition and dissolution overpotentials. Therefore, further development of LLZ is required to obtain an electrolyte that remains lithium dendrite-free at high current densities for long periods.

\section{Conclusion}

Garnet-type lithium conducting solid electrolytes with the nominal $\mathrm{Li}_{7} \mathrm{La}_{3} \mathrm{Zr}_{2} \mathrm{O}_{12}$ composition and with various $\mathrm{Al}_{2} \mathrm{O}_{3}$ contents were prepared by solid state reaction at $1180{ }^{\circ} \mathrm{C}$. The grain boundary resistance of $\mathrm{Al}_{2} \mathrm{O}_{3}$-doped $\mathrm{LLZ}$ and the interface resistance between lithium metal and $\mathrm{Al}_{2} \mathrm{O}_{3}$-doped $\mathrm{LLZ}$ are significantly dependent on the $\mathrm{Al}_{2} \mathrm{O}_{3}$ content. The lowest grain boundary resistance and interface resistance were obtained for 0.5 wt\% $\mathrm{Al}_{2} \mathrm{O}_{3}$-doped LLZ. $\mathrm{Li} / \mathrm{Al}_{2} \mathrm{O}_{3}$-doped LLZ/Li cells exhibited abrupt cell voltage drops under polarization after fairly short periods, which were dependent on the $\mathrm{Al}_{2} \mathrm{O}_{3}$ content in LLZ. The longest period before the abrupt cell voltage drop was observed for $0.5 \mathrm{wt} \% \mathrm{Al}_{2} \mathrm{O}_{3}$-doped LLZ. The voltage drop is considered to be due to lithium dendrite formation. The mechanism for dendrite formation at the interface between lithium metal and the LLZ has yet to be clarified, but it is known that the rate of lithium dendrite formation is affected by the density of the sintered LLZ electrolyte.

\section{Acknowledgment}

This study was supported by the Japan Science and Technology Agency (JST) under the 
project “Advanced Low Carbon Technology and Development Program”.

\section{References}

[1] R. Murugan, V. Thangaduri, W. Weppner, Angew. Chem. Int. Ed., 46 (2007) 7778

[2] Y. Shimonishi, A. Toda, T. Zhang, A. Hirano, N. Imanishi, O. Yamamoto, Y. Takeda, Solid State Ionics, 183 (2011) 48

[3] C. Brissot, M. Rosso, J.N. Chlavazlviel, S. Lauscaud, J. Power Sources, 81 (1999) 925

[4] G.B. Appetecchi, F. Croce, G. Dautchemberg, M. Mastragostino, F. Ronci, B. Scrosati, F. Soavi, A. Zanelli, F. Alessandrini, P.P. Prosini, J. Electrochem. Soc., 145 (1998) 4126

[5] S. Liu, N. Imanishi, T. Zhang, A. Hirano, Y. Takeda, O. Yamamoto, J. Yang J. Electrochem. Soc., 157 (2010) A1092

[6] E. Peled, J. Electrochem. Soc., 126 (1979) 2047

[7] M. Kotobuki, H. Munakata, K. Kanamura, Y. Sato, T. Yoshida, J. Electrochem. Soc., 157 (2010) A1076

[8] S. Ohta, T. Kobayashi, J. Seki, T. Asaoka, J. Power Sources, 202 (2012) 332

[9] Y. Nakata, K. Ishiguro, M. Matsui, A. Hirano, O. Yamamoto, N. Imanishi, $53^{\text {rd }}$ Battery Symp. Japan, Abst. 3G17, Fukuoka, Japan, 2012

[10] C.A. Geiger, E. Alekseev, B. Lazic, M. Fisch, T. Armbruster, R. Langner, M. Fechtekord, N. Kim, T. Pettek, W. Weppner, Inorg. Chem., 50 (2011) 1089

[11] E. Rangasamy, J. Wolfenstine, J. Sakamoto, Solid State Ionics, 206 (2012) 28

[12] J. Awaka, A. Takashima, K. Kataoka, N. Kijima, Y. Idemoto, J. Akimoto, Chem. Lett., 40 (2011) 60

[13] S. Kumazaki, Y. Iriyama, K.-H. Kim, R. Murugan, K. Tanabe, K. Yamamoto, T. Hirayama, Z. Ogumi, ～Electrochem. Comm., 13 (2011) 509

[14] Y. Jin, P. McGinn, J. Power Sources, 196 (2011)8683

[15] P.G. Bruce, A.R. West, J. Electrochem. Soc., 130 (1983) 662

[16] T. Zhang, N. Imanishi, S. Hasegawa, A. Hirano, J. Xie, Y. Takeda, O. Yamamoto, N. Sammes, J. Electrochem. Soc., 156 (2008) A965

[17] H. Wang, D. Im, D.J. Lee, M. Matsui, Y. Takeda, O. Yamamoto, N. Imanishi, J. Electrochem. Soc., 160 (2013) A728

[18] K.Ishiguro, Y.Nakata, M.Matsui, I.Uechi, Y.Takeda, O.Yamamoto, N.Imanishi, J. Electrochem.Soc., 160 (2013) A1690 
Figure captions

Fig. 1. Impedance profiles for $\mathrm{Au} / \mathrm{Al}_{2} \mathrm{O}_{3}$-doped LLZ/Au measured at $25^{\circ} \mathrm{C}$.

$\bigcirc: \mathrm{LLZ}, \square: 0.5 \mathrm{wt} \% \mathrm{Al}_{2} \mathrm{O}_{3}$-doped LLZ, $\diamond: 1 \mathrm{wt} \% \mathrm{Al}_{2} \mathrm{O}_{3}$-doped LLZ, $\triangle$ : $2.0 \mathrm{wt} \% \mathrm{Al}_{2} \mathrm{O}_{3}$-doped LLZ.

Fig. 2. Impedance profiles for $\mathrm{Li} / \mathrm{Al}_{2} \mathrm{O}_{3}$-doped LLZ/Li measured at $25{ }^{\circ} \mathrm{C}$.

(a) LLZ, (b) $0.5 \mathrm{wt} \% \mathrm{Al}_{2} \mathrm{O}_{3}$-doped LLZ, (c) $1.0 \mathrm{wt} \% \mathrm{Al}_{2} \mathrm{O}_{3}$-doped LLZ, (d) 2.0 wt $\% \mathrm{Al}_{2} \mathrm{O}_{3}$-doped LLZ.

Fig. 3. Cell voltage vs. time curves for $\mathrm{Li} / \mathrm{Al}_{2} \mathrm{O}_{3}$-doped LLZ/Li cells at $0.5 \mathrm{~mA} \mathrm{~cm}{ }^{-2}$ as a function of the $\mathrm{Al}_{2} \mathrm{O}_{3}$ content measured at $25^{\circ} \mathrm{C}$.

(a): LLZ, (b): $0.5 \mathrm{wt} \% \mathrm{Al}_{2} \mathrm{O}_{3}$-doped LLZ, (c) $1.0 \mathrm{wt} \% \mathrm{Al}_{2} \mathrm{O}_{3}$-doped LLZ, (d) 2.0 wt $\% \mathrm{Al}_{2} \mathrm{O}_{3}$-doped LLZ.

Fig. 4. (a) Schematic presentation of assembly of the dendrite growth visible cell and the surface morphology change by polarization at $0.5 \mathrm{~mA} \mathrm{~cm}^{-2}$ for (b) 0 , (c) 280 and (d) $840 \mathrm{~s}$ 
Table $1 \mathrm{Al}$ and $\mathrm{Li}$ contents, lattice constant and relative density of $\mathrm{Al}_{2} \mathrm{O}_{3}$-doped LLZ

\begin{tabular}{|c|c|l|c|c|c|c|}
\hline \multicolumn{2}{|c|}{ Starting materials } & \multicolumn{2}{|c|}{$\begin{array}{c}\mathrm{Al} \text { and } \mathrm{Li} \text { content of } \\
\text { sintered } \mathrm{Al}_{2} \mathrm{O}_{3} \text {-doped } \\
\text { LLZ (wt\%) }\end{array}$} & $\begin{array}{c}\text { Lattice constant } \\
(\mathrm{nm})\end{array}$ & $\begin{array}{c}\text { Relative } \\
\text { density } \\
(\%)\end{array}$ \\
\hline $\mathrm{Al}_{2} \mathrm{O}_{3}$ & $\mathrm{Al}$ & $\mathrm{Li}$ & $\mathrm{Al}$ & $\mathrm{Li}$ & & \\
\hline 0 & 0 & 6.28 & 0.6 & 5.4 & 1.29676 & 89.6 \\
\hline 0.5 & 0.26 & 6.25 & 0.79 & 5.3 & 1.29684 & 93.7 \\
\hline 1.0 & 0.54 & 6.22 & 0.98 & 5.2 & 1.29734 & 91.5 \\
\hline 20 & 1.08. & 6.17 & 1.18 & 5.1 & 1.29689 & 90.0 \\
\hline
\end{tabular}

Table 2 Electrical conductivity of $\mathrm{Al}_{2} \mathrm{O}_{3}$-doped LLZ

\begin{tabular}{|c|c|c|c|}
\hline \multirow{2}{*}{$\begin{array}{c}\mathrm{Al}_{2} \mathrm{O}_{3} \text { content } \\
(\text { wt \%) }\end{array}$} & \multicolumn{3}{|c|}{ Electrical conductivity $\left(\mathrm{S} \mathrm{cm}^{-1}\right)$} \\
\cline { 2 - 4 } & $2.33 \times 10^{-4}$ & Bulk & Grain boundary \\
\hline 0 & $4.12 \times 10^{-4}$ & $5.26 \times 10^{-4}$ & $4.17 \times 10^{-4}$ \\
\hline 0.5 & $2.99 \times 10^{-4}$ & $4.38 \times 10^{-4}$ & $1.67 \times 10^{-3}$ \\
\hline 1.0 & $1.77 \times 10^{-4}$ & $3.46 \times 10^{-4}$ & $9.43 \times 10^{-4}$ \\
\hline 2.0 & & $3.46 \times 10^{-4}$ \\
\hline
\end{tabular}


Sudo Fig. 1
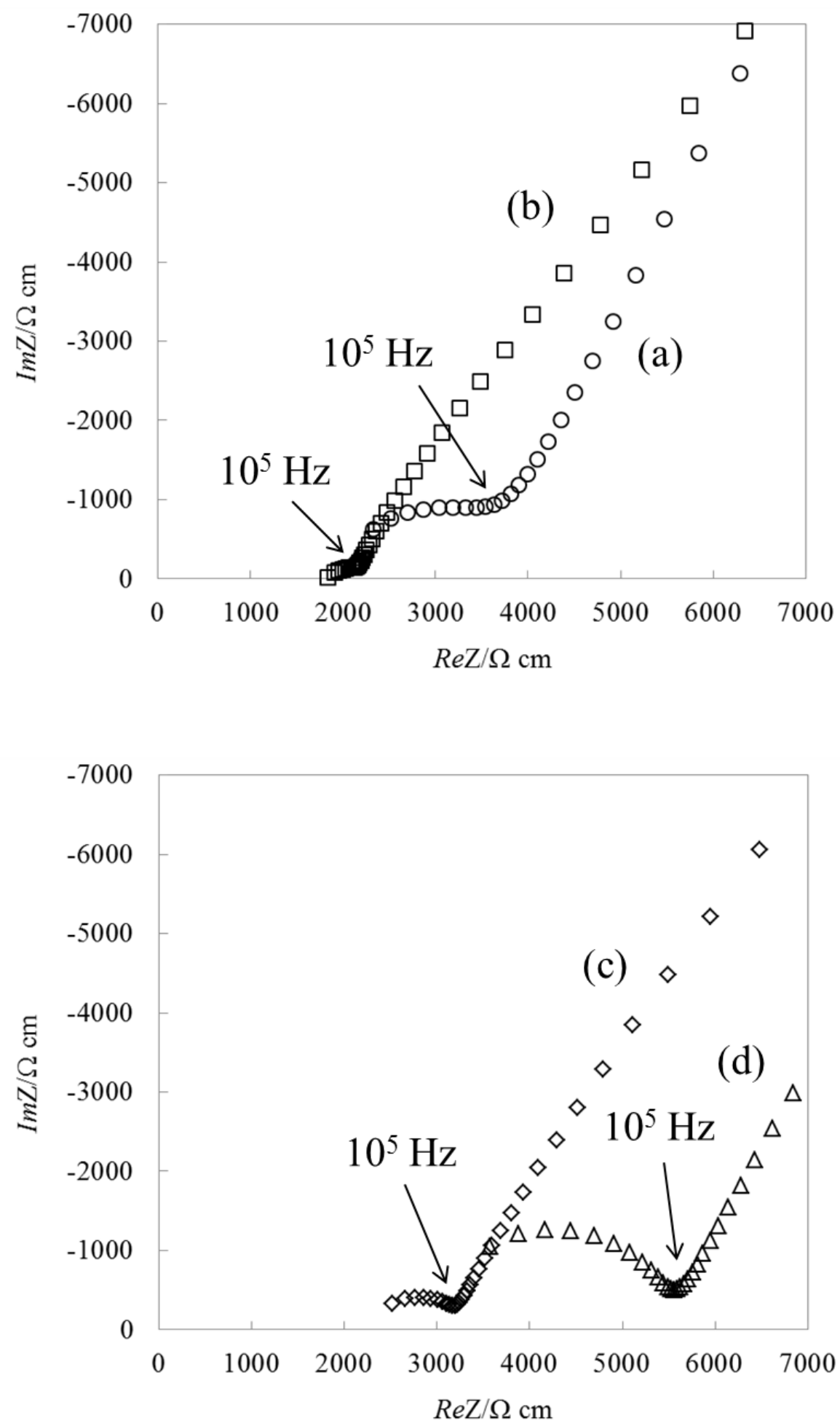
Sudo Fig. 2
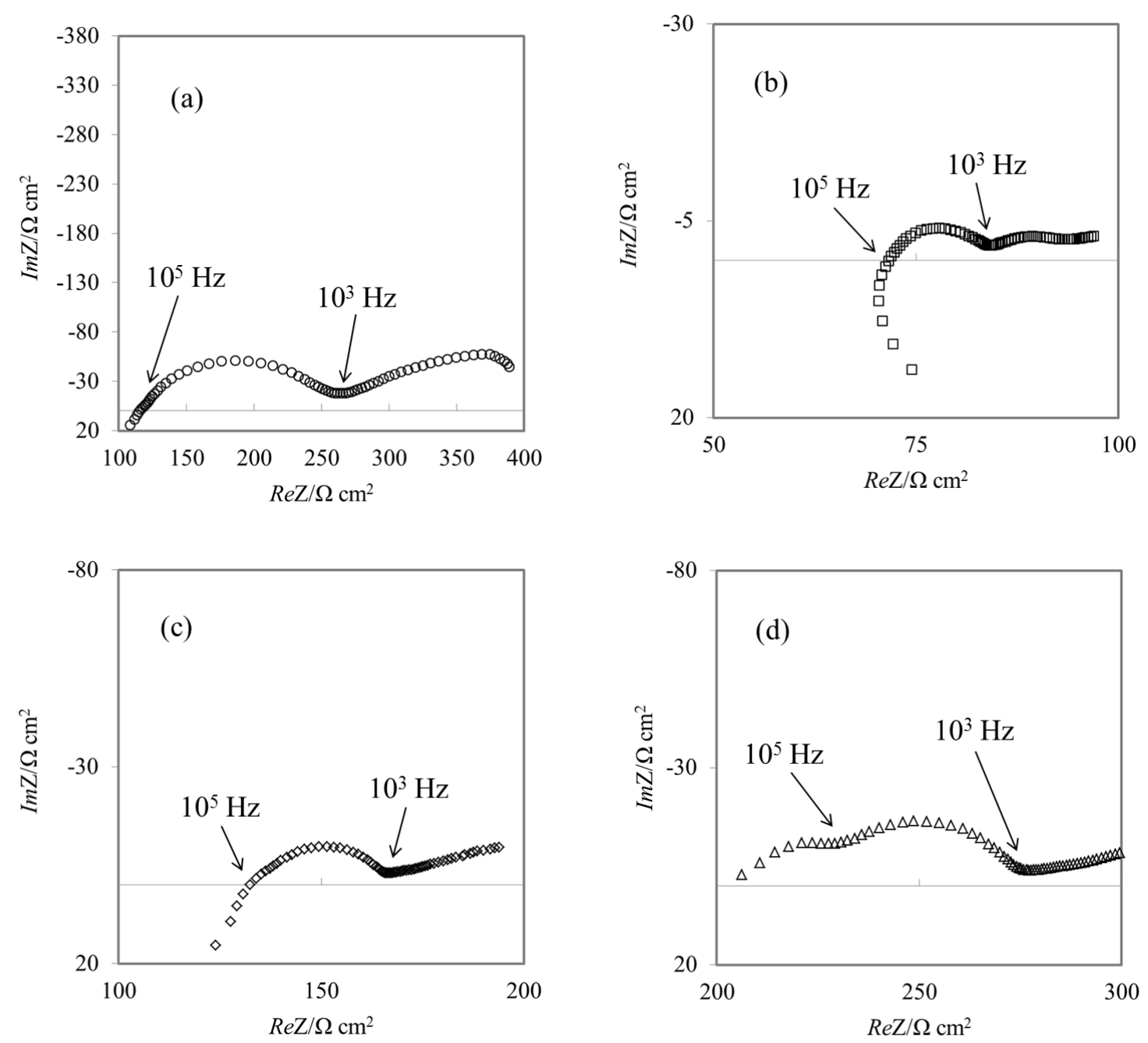
Sudo Fig.3

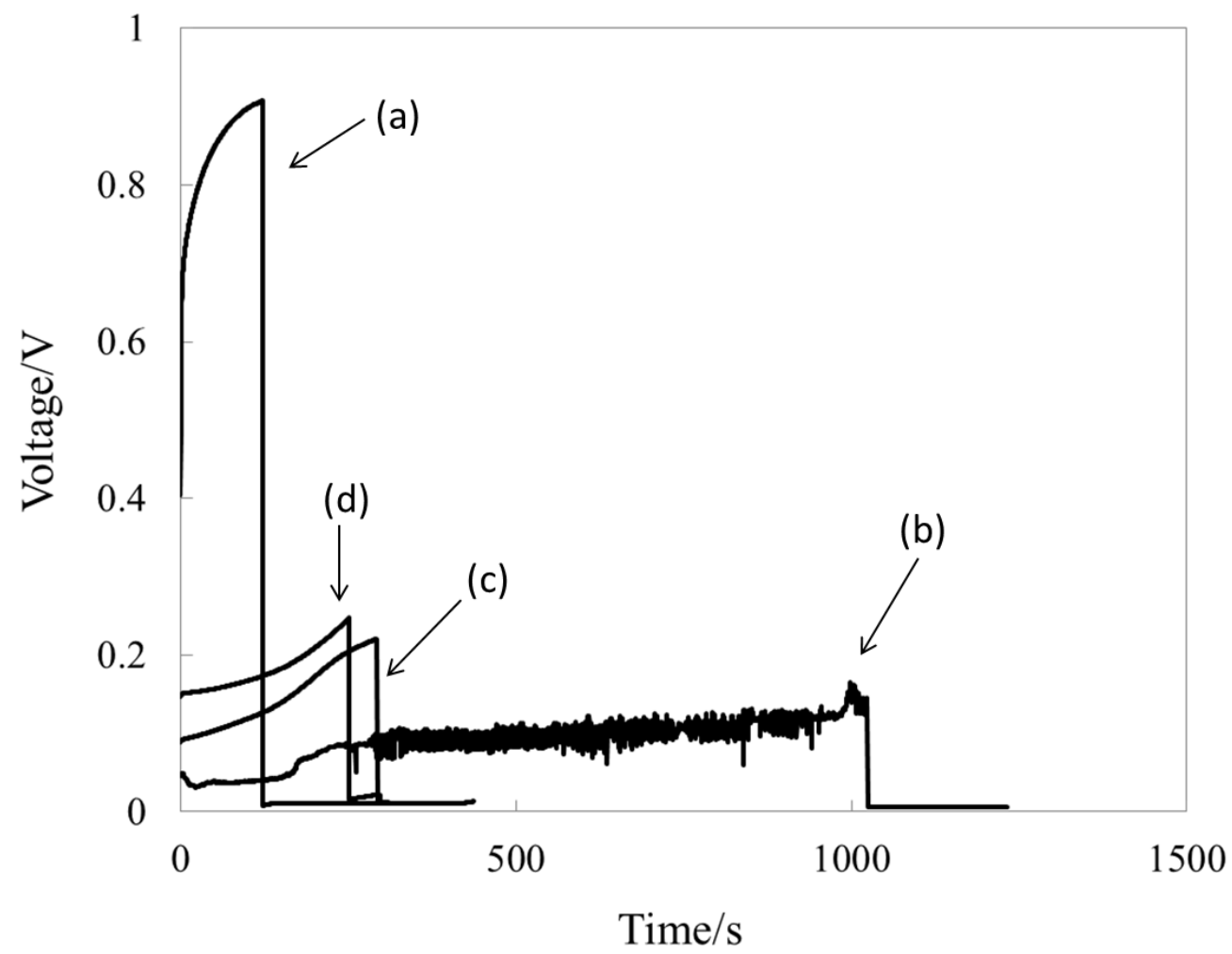


Sudo Fig.4

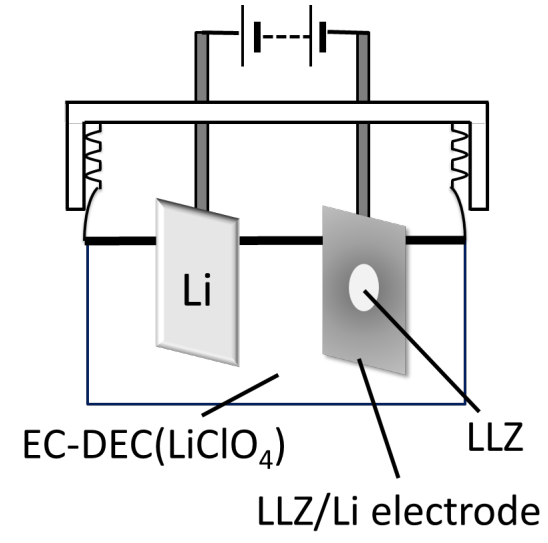

(a)

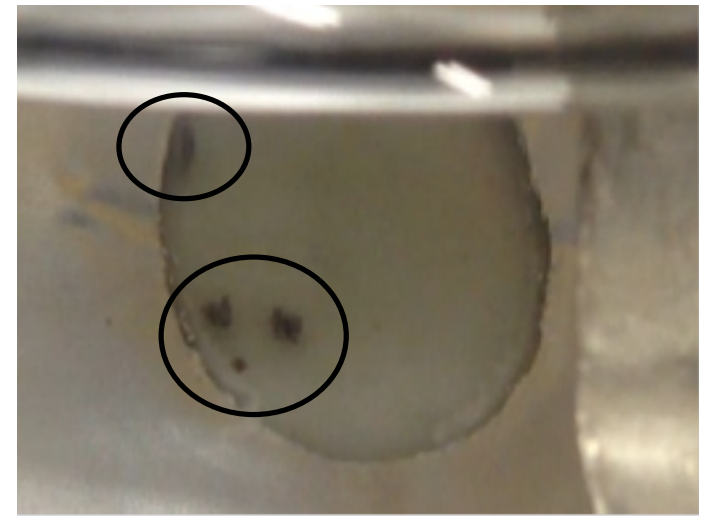

$280 \mathrm{~s}$

(c)

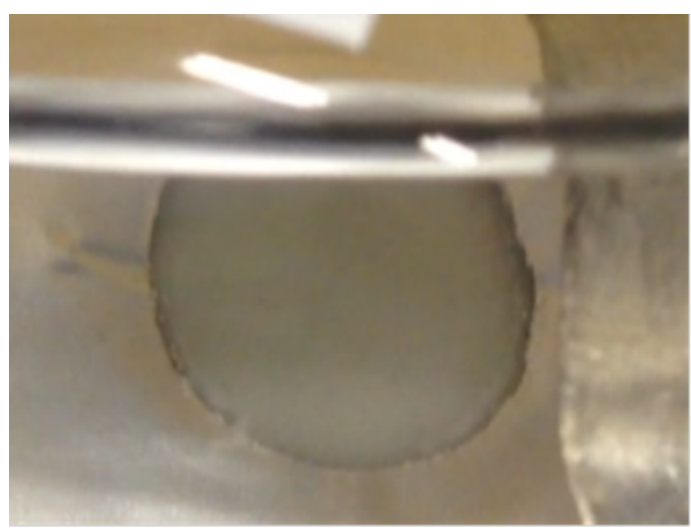

$0 \mathrm{~s}$

(b)

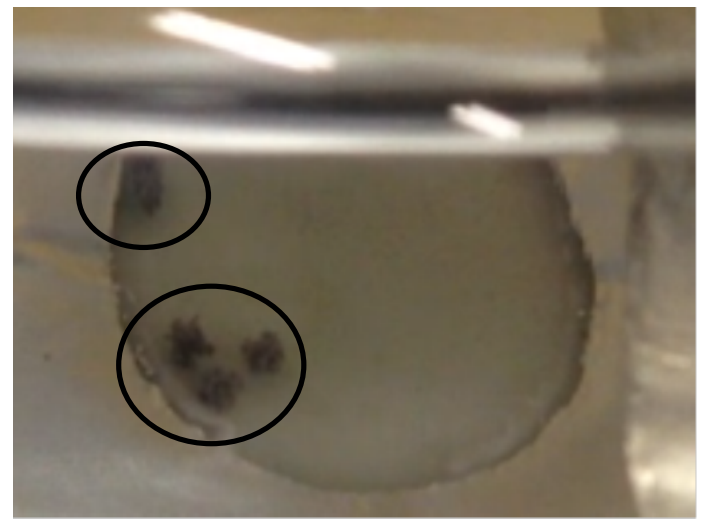

$840 \mathrm{~s}$

(d) 